Insight

\title{
The Next Generation of Scientists: Examining the Experiences of Graduate Students in Network-Level Social-Ecological Science
}

\author{
Michele Romolini $^{1}$, Sydne Record $^{2}, \underline{\text { Rebecca Garvoille }}^{3}, \underline{\text { Yevgeniy Marusenko }}^{4}$ and $_{\text {R. Stuart Geiger }}^{5}$
}

\begin{abstract}
By integrating the research and resources of hundreds of scientists from dozens of institutions, network-level science is fast becoming one scientific model of choice to address complex problems. In the pursuit to confront pressing environmental issues such as climate change, many scientists, practitioners, policy makers, and institutions are promoting network-level research that integrates the social and ecological sciences. To understand how this scientific trend is unfolding among rising scientists, we examined how graduate students experienced one such emergent social-ecological research initiative, Integrated Science for Society and Environment, within the large-scale, geographically distributed Long Term Ecological Research (LTER) Network. Through workshops, surveys, and interviews, we found that graduate students faced challenges in how they conceptualized and practiced social-ecological research within the LTER Network. We have presented these conceptual challenges at three scales: the individual/project, the LTER site, and the LTER Network. The level of student engagement with and knowledge of the LTER Network was varied, and students faced different institutional, cultural, and logistic barriers to practicing social-ecological research. These types of challenges are unlikely to be unique to LTER graduate students; thus, our findings are relevant to other scientific networks implementing new social-ecological research initiatives.
\end{abstract}

Key Words: graduate students; interdisciplinary research; LTER Network; social-ecological

\section{INTRODUCTION}

Many of today's major scientific challenges, e.g., climate change, atmospheric modeling, epidemiology, genome sequencing, and high-energy physics, are inadequately addressed by a single research team at a single institution with a single disciplinary focus (Wilson 1999, Ewel 2001, Díaz et al. 2011). Complex research questions often require a collaborative approach that reaches across disciplines, which is becoming an increasingly prevalent scientific model (Nature Editorial Board 2003, Norgaard and Baer 2005, Carpenter et al. 2007). As a result, scientific endeavors are often carried out by organizations of researchers spanning dozens to hundreds of geographic sites. Network-level science is one term used to describe this mode of large-scale, geographically dispersed, integrative research made possible by connecting researchers, data sets, and resources to solve a common set of scientific problems (Karasti and Baker 2008, Porter et al. 2009).

Network-level science has proved effective in scientific investigations that involve collection, synthesis, and analysis of massive amounts of data. This approach is also needed when the range of phenomena under examination requires a comparable range of academic expertise, as in contemporary ecology, where research on the complex social-ecological drivers of regional and global environmental change necessitates collaborations across the biophysical and social sciences (Norgaard and Baer 2005, Carpenter et al. 2007). As such, several large-scale distributed scientific networks, e.g., the Resilience Alliance, the National Ecological Observatory
Network, and the Long Term Ecological Research (LTER) Network, have been established to conduct social-ecological research across broad spatial and temporal scales. However, not all scientific questions necessitate a network of researchers undertaking massive data collection and analysis, and scholars have long raised concerns about how the inclusion of multiple perspectives in research may impact the scientific process (Shapin and Schaffer 1985). Despite this, few studies critically examine the ways in which scientific networks operate. Existing research largely focuses on logistic and communicative issues that arise when connecting researchers with different institutional, cultural, disciplinary, and methodological backgrounds (Heemskerk et al. 2003, Rhoten and Parker 2004).

Network-level science is often advanced by early career researchers, who are typically products of innovative and successful graduate programs (Graybill and Shandas 2010). Historians and sociologists of science have shown that graduate students and research assistants are profoundly influential in how science is produced and distributed across geographic and disciplinary boundaries (Shapin and Schaffer 1985, Galison 1997). Scientists have also acknowledged myriad challenges, such as differences in theories, methodologies, and overall values, associated with collaborative team research across disciplines and suggest the need for continuous dialogue and programmatic restructuring to address issues as they arise (Nature Editorial Board 2003, Lélé and Norgaard 2005). Graduate students make important contributions to ongoing debates about interdisciplinary

${ }^{1}$ Center for Urban Resilience, Loyola Marymount University, ${ }^{2}$ Harvard Forest, Harvard University, ${ }^{3}$ Department of Conservation and Forestry, University of Montana, ${ }^{4}$ School of Life Sciences, Arizona State University, ${ }^{5}$ School of Information, University of California Berkeley 
research and training in network-level science (Price 1990, Gilbert 1998, Graybill et al. 2006, Haythornthwaite et al. 2006, MacMynowski 2007). However, few studies have focused on the lived experiences of graduate students in network-level scientific projects (Morse et al. 2007).

We have focused on how graduate students conceptualize and practice social-ecological research within the U.S. LTER Network. The National Science Foundation (NSF) founded the LTER Network in 1980 to encourage ecological research spanning broad temporal and spatial scales (Callahan 1984). Since 1980, the LTER Network has developed from a collection of independent sites focusing strictly on ecological research into a largely collaborative, densely connected research network (Johnson et al. 2010) that promotes socialecological research. Indeed, lead scientists recently suggested changing the name to Long Term Social-Ecological Research to explicitly recognize the key role of social science in the network (Haberl et al. 2006). At present, the LTER Network is in the implementation phase of the Integrated Science for Society and Environment (ISSE) initiative, a 10-year plan to promote social-ecological research (U.S. LTER Network 2007, Collins et al. 2011). The ISSE recognizes graduate students as the next generation of lead scientists in the LTER Network by stressing the importance of supporting socialecological graduate student research. At the same time, senior scientists studying social-ecological systems are grappling with the appropriate approach to disciplinarity, whether it is multidisciplinary, interdisciplinary, transdisciplinary, or another mode of research (Miller et al. 2008). We have followed the definitions of Miller et al. (2008), who describe multidisciplinary research as a situation in which "individual researchers consider a common set of issues, but maintain disciplinary boundaries"; interdisciplinary research as a more integrated approach with "unified problem formulation, sharing of methods, and perhaps the creation of new questions"; and transdisciplinary research as "transcend[ing] entrenched categories to formulate problems in new ways." As new social-ecological scientists, graduate students are challenged to choose the appropriate approach to disciplinarity and navigate this emergent and complex field of research.

Our research traced how LTER graduate students interpreted, put into practice, and reformulated the novel ideas put forward through the ISSE initiative. We examined how graduate students conceptualized and practiced social-ecological research at three scales: the individual/project, the LTER site, and the LTER Network levels. Although the results are highly relevant for members of other research networks that seek to integrate social and ecological science, we have explored potential issues for all interdisciplinary, network-level scientific projects. We found that the disparate experiences of LTER graduate students revealed the complex nature of how scientific networks operate and the unique concerns that their members face. Although not representative of network-level science in general or even the LTER Network as a whole, the different ways in which graduate students understood and negotiated what it meant to be networked, social-ecological scientists provided insights into how network-level science operates, how networks can best adopt novel social-ecological research initiatives, and how to build a strong foundation for the future of network-level science.

\section{METHODS}

To document the experiences of graduate students with socialecological research in the LTER Network, we used a study design that combined focus group interviewing with survey research and semistructured interviews. A mixed methods approach enabled us to collect study data at multiple scales and to triangulate our data (Fig. 1).

Fig. 1. In this study we employed three iterative rounds of data collection from surveys to interviews. Analysis of the coded interviews alongside the survey data revealed general trends in responses across different scales in the Long Term Ecological Research (LTER) Network.

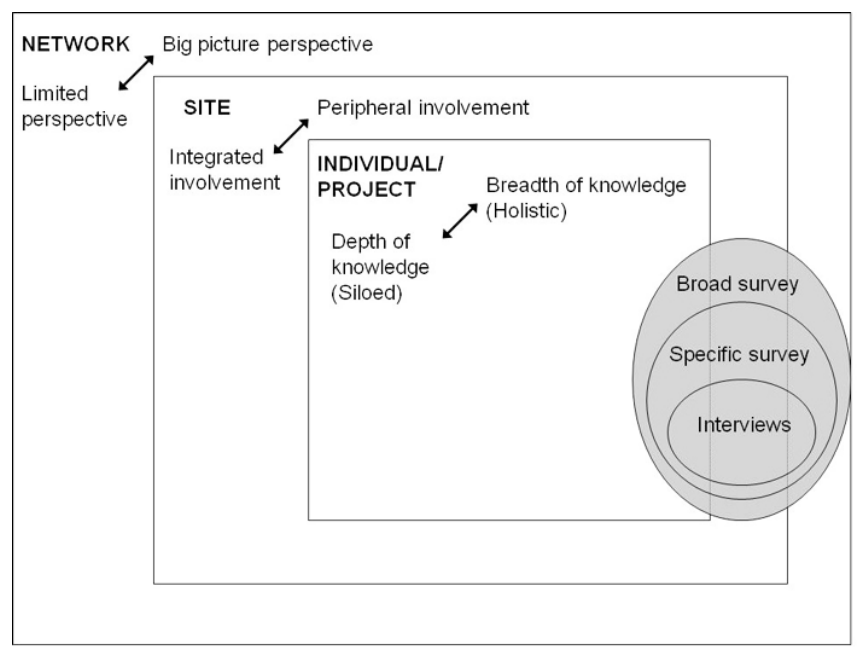

We began with a focus group among graduate students, called "Benefits and Barriers to Social-Ecological Research," at the 2009 LTER All Scientists Meeting (ASM) in Estes Park, Colorado. A focus group is a structured or unstructured group discussion about a topic of interest led or observed by researchers (Edmunds 2000, Berg 2007). In the session, 19 graduate students from 6 LTER sites discussed the challenges they faced in carrying out social-ecological research in the LTER Network. It is important to acknowledge that we, the authors, were LTER graduate students who initially participated in the ASM focus group and then subsequently assumed the role of project investigators observing other LTER scientists. We recognize our positions within the LTER Network and make no claims to pure objectivity. Instead, our 
research represents a kind of "situated knowledge" (Haraway 1988) and is the product of our own embodied and contingent experiences working in and studying the LTER Network.

The focus group proved a useful strategy for gathering preliminary data on LTER graduate students' experiences with social-ecological research, and we used this information to frame specific project research questions and to develop two separate, structured surveys. Each survey contained a combination of closed and open-ended questions and was pretested with volunteers. First, we distributed a broad, 31question online survey to all the graduate student members of the LTER Network's student Listserv (Appendix 1). The LTER Network's student Listserv includes approximately 650 LTER graduate and undergraduate student members. Then, to collect more specific data from students who had conducted social-ecological research, we e-mailed a targeted, 17question survey to 42 graduate students identified by senior LTER scientists as being involved with social-ecological research (Appendix 2). We gathered data from 103 students, 57 fully completed responses, for the broad survey and from 41 respondents, 33 fully completed responses, for the targeted survey. Data for categorical questions were tallied and reported as percentages of the total number of responses.

The broad survey asked questions about the types of research students were conducting, institutional and disciplinary affiliations, familiarity with and attitudes toward socialecological research, and the challenges and opportunities related to the pursuit of social-ecological research. The targeted survey expanded on the broad survey by asking more specific questions about students' definitions of and direct experiences with social-ecological research in the LTER Network, and targeted survey respondents were asked to indicate their willingness to participate in follow-up interviews. Results from both surveys were analyzed to reveal patterns across survey responses. To add greater depth and context to the survey data, we used the findings as a guide to design a semistructured interview protocol (Appendix 3). Interview questions asked graduate students to more specifically describe their engagements with social-ecological research in the LTER Network at the individual/project level, the site level, and the network level. Hour-long semistructured phone interviews were carried out with 10 current or recently graduated students who volunteered to participate and who self-identified as conducting a social-ecological project in the LTER Network. This phased survey and interview approach employed a sampling design with intentional biases. Although we used random sampling for the broad survey, we chose purposive sampling for both the targeted survey and the interviews to locate students who had experiences with socialecological research in the LTER Network.

We used a combination of inductive open coding and deductive coding to analyze our interview data. Using
ExpressScribe and Microsoft Word, we transcribed and then coded the interviews into specific categories related to challenges in social-ecological research. In an initial round of coding, we searched for quotes and expressions relevant to preidentified categories such as "funding challenges," "site challenges," "network challenges," "adviser challenges," and "methodological challenges" (see Ryan and Bernard 2003). In a second stage of coding, we used open coding to inductively identify key concepts and categories beyond those included in the original list of categories (Corbin and Strauss 2008) but related to the definitions and challenges of social-ecological research. We constantly compared notes to develop a consistent framework for coding the interviews. Analysis of the coded interviews alongside the survey data revealed general trends in responses across data sources and in experiences across different scales in the LTER Network (Fig. $1)$.

\section{RESULTS AND DISCUSSION}

Our results demonstrated that graduate student experiences with social-ecological research in the LTER Network were defined by several key conceptual challenges. We discuss how these challenges manifested at three scales in the LTER Network, i.e., the individual/project, the site, and the network levels, and along two dimensions at each scale, i.e., conceptualization and practice. Table 1 provides examples of the types of unstated conceptual challenges that LTER graduate students may experience at these scales.

\section{Individual/project level}

\section{Conceptualization}

Graduate students had different definitions of socialecological research and different understandings of what it means to be a social-ecological researcher in the LTER Network. The LTER Network's ISSE plan asserted that "new research must focus on understanding the long-term dynamic processes that are unique to social-ecological systems versus purely social or purely biophysical systems" (U.S. LTER Network 2007:6). However, the results from our broad survey demonstrated that graduate students struggled to concretely define the term social-ecological. Only $4 \%$ of respondents felt that there was an agreed upon definition of social-ecological research within the LTER Network, and only $33 \%$ felt that they could clearly define social-ecological research. Indeed, when asked to define social-ecological research in their own words, only $57 \%$ of graduate students chose to respond to the question.

Those who did respond offered a general definition of socialecological research as the study of the interactions between human systems and ecosystems. A simple word-frequency analysis (Fig. 2), created using http://www.wordle.net, revealed that the top five terms students used to define socialecological research were research, interaction, human, 
Table 1. Examples of the types of challenges that Long Term Ecological Research (LTER) graduate students may experience with the conceptualization and practice of social-ecological research at the individual, site, and network scales.

\begin{tabular}{|c|c|c|}
\hline & Conceptualization & Practice \\
\hline $\begin{array}{l}\text { Individual/ project } \\
\text { scale }\end{array}$ & $\begin{array}{l}\text { What counts as social-ecological research? } \\
\text { Who is a social-ecological researcher? } \\
\text { Should I focus on breadth or depth? }\end{array}$ & $\begin{array}{l}\text { How do my collaborators and I conduct social-ecological } \\
\text { research? } \\
\text { Are siloed or holistic approaches better for social-ecological } \\
\text { projects? }\end{array}$ \\
\hline Site scale & $\begin{array}{l}\text { How connected am I with students and researchers } \\
\text { at my site? } \\
\text { Do I even have a field site? }\end{array}$ & $\begin{array}{l}\text { How far away is my university/PI from my site? } \\
\text { How does my site help me conduct my research? }\end{array}$ \\
\hline Network scale & $\begin{array}{l}\text { What is the LTER doing to support social- } \\
\text { ecological research? } \\
\text { What is the LTER, anyway? }\end{array}$ & $\begin{array}{l}\text { Am I a member of the LTER? } \\
\text { How important is the LTER for my social-ecological } \\
\text { research projects? }\end{array}$ \\
\hline
\end{tabular}

ecological, and systems. However, graduate students described the interactive relationship between humans and ecosystems in many different ways. Several students characterized social-ecological research as a one-directional research field, emphasizing the study of human impacts on the ecosystem rather than examining humans as part of the ecosystem. Other graduate students characterized socialecological research as a type of outreach or education to the general public, a core aspect of the LTER Network's mission.

In addition to divergent ideas about its definition, we found that graduate students involved in social-ecological research articulated different understandings of what it means to be a social-ecological researcher. In the interviews, students frequently referenced the depth-versus-breadth debate surrounding disciplinary specialization (Gilbert 1998, Morse et al. 2007). The depth understanding is multidisciplinarity, which holds that students should primarily identify with a single social or ecological discipline, becoming an expert in the theories and methods of that one particular approach. Students then become social-ecological researchers by applying their disciplinary specialization alongside other researchers in a multidisciplinary setting and learning to communicate with other disciplinary experts. As one interviewee stated: "We should all have expertise ... the disciplinary knowledge is really important, but I think we should have enough background in each other's disciplines to be able to read studies, read papers, evaluate methods ... we each bring different skills to the table and we need to rely on those sometimes to get the actual work done in the best way."

In contrast, students with a breadth view were more aligned with interdisciplinarity or transdisciplinarity and did not necessarily identify with or consider themselves experts in a single discipline. They were trained to have a range of knowledge, skills, and expertise that allows them to conduct research that integrates multiple disciplines, either on their own or in collaboration with other researchers. One student described how she was “... trying to frame myself as more of a synthetic person, someone who knows enough about all of these other disciplines that I can piece together the puzzle. Not trying to actually be an ecologist, be a planner, be a geographer, be all of these things ... people tell you that there are going to be challenges in the future, finding jobs, because you need to have a discipline. But I really don't think that's going to be the case."

\section{Practice}

The concept of specializing in one field versus gaining broader training in multiple fields was also evident in how socialecological projects were carried out. From our interviews, we found that students who had participated in one or more collaborative social-ecological projects described these projects as falling along a continuum from a siloed, or multidisciplinary, project approach to a holistic, or transdisciplinary, project approach (Eigenbrode et al. 2007). Their narratives pointed to the variety of modes of practice that currently exist for social-ecological research in the LTER Network (Fig. 1).

Graduate students involved in siloed projects described how disciplinary researchers were seen as independent from each other and were asked to approach a clearly delineated part of a research project from within their single area of expertise. Some interviewees viewed the siloed model as a normal, accepted, and even exemplary approach to social-ecological research, whereas others were critical of it. For example, one student working on a study employing social and ecological methods was critical of her experience with a siloed collaborative process, stating: "Each researcher is bringing their one component to the project that will then somehow be synthesized in the end. There doesn't seem to be much emphasis on having everyone on the same page or having everyone understand everything else."

Graduate students involved in holistic projects described how researchers were more involved in each other's activities throughout the project, jointly forming and reformulating 
Fig. 2. A visual representation of the most frequent terms Long Term Ecological Research (LTER) graduate students used when asked to define social-ecological research, with the size of the word indicating the frequency of its use.

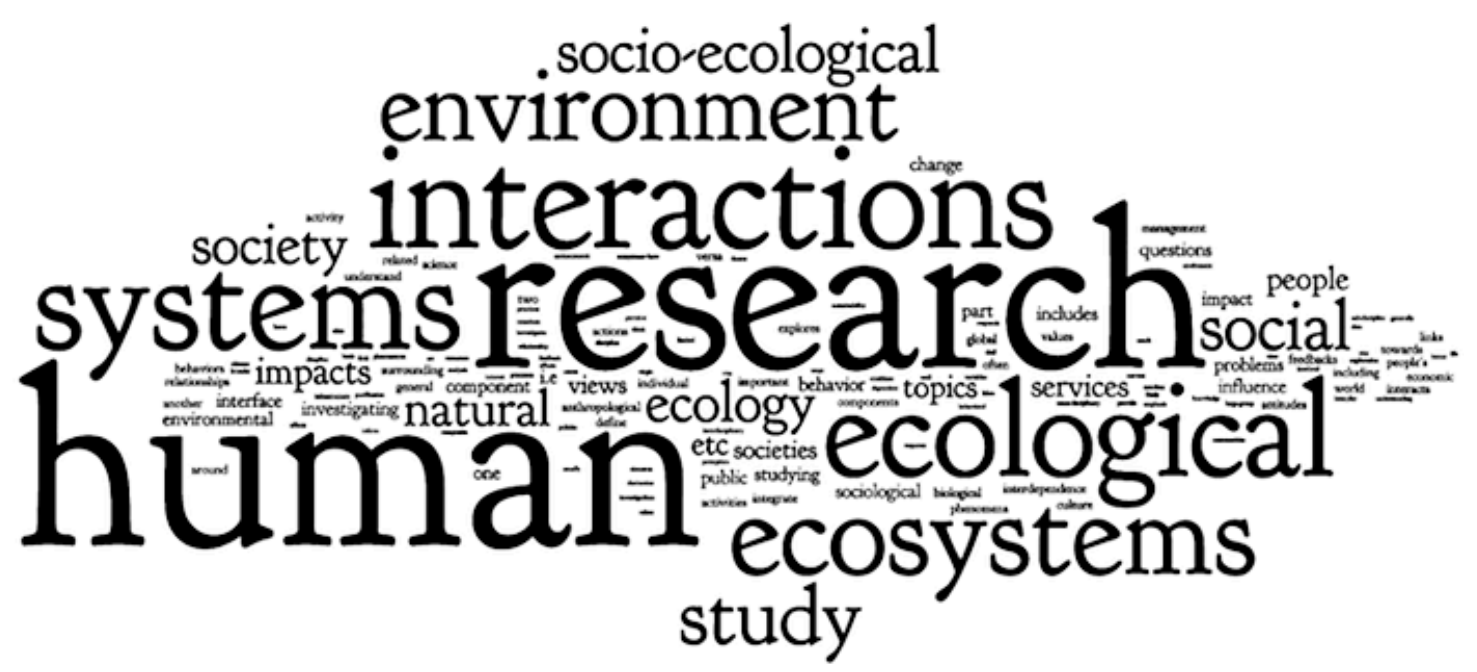

research questions, as well as collaboratively collecting and analyzing data. For instance, one student praised this holistic approach: "Rather than just doing ecology and then bringing in the social scientists on the side, it's about creating interdisciplinary ideas and methods, and thinking about that from the beginning, so that at the end you have a project that is integrated throughout."

\section{LTER site level}

\section{Conceptualization}

Graduate students discussed how LTER sites varied in the way they incorporated social-ecological research into the scale and scope of their research, raising questions about traditional LTER site organization. As other scholars have noted, integrated social-ecological projects often face the challenge of scale mismatch (Pickett 1999, Redman et al. 2004); that is, the biophysical and social variables are not studied at the same geographic scales. Scale and integration were definite challenges for graduate students working on LTER socialecological research. One interviewee working on an LTERaffiliated social-ecological project with broader boundaries than his official LTER site noted that his interactions with other site personnel and his overall sense of connection to his LTER site were limited because he was not based at the traditional field site during the regular field season. He noted: "We are not terribly well integrated into the LTER. [Our site] tends to think of its research as what goes on 'within the fence' ... Since we are not physically on site during the season the way that most researchers are, it's a little peripheral to that."

Another interviewee, who also worked on a social-ecological project with boundaries broader than those of his official
LTER site and was not based at the site's research station, observed: "I know that there is a kind of field study house located within [and] maintained by the site [that] is used for doing the very traditional ecological research ... I get the impression that there is a much more closely connected network of researchers out there who work on ecological issues. I don't really have any connection to those folks." The remarks of the interviewees belie a sense of frustration at being in a more marginal position to the main hubs of research activity and intellectual exchange at their LTER sites.

\section{Practice}

When considering the practice of social-ecological research at the site level, some graduate students discussed challenges associated with spatial and cultural distance, whereas several others described strong site-level support. Graduate students described varied levels and modes of involvement at their home LTER sites. Although some LTER sites have principal investigators (PIs) strongly linked to one particular university and a field location with specific boundaries, others have PIs dispersed throughout the country and study areas that vary widely in geographic location and scale. In fact, $64 \%$ of the graduate student respondents in the broad survey were located at universities greater than 50 miles from their LTER sites.

Students at sites characterized by dispersed researchers, universities, and field locations tended to have greater difficulty in engaging with their site and, therefore, understanding if or how social-ecological research was operating at their site. One student attending a university separated from the LTER site by hundreds of miles had scheduling conflicts. He told us: "The tough part about 
working with [the LTER site personnel] was that their schedule was based on the semester system and [my university] is based on the quarter system, so we could never go to their meetings."

Other students struggled to find support for the social sciences or other social scientists working at their LTER site. One interviewee observed that incorporating the social sciences was an NSF mandate that was not yet generally accepted within his site. He explained that "the renewal of their LTER was really contingent on becoming more transdisciplinary, involving social science. And I think it's been a really challenging transition for them."

However, we also interviewed students who felt a strong level of integration into their local sites. These students reported that other students and faculty at their sites were conducting a substantial amount of social-ecological research, as well as collaborating on various short- and long-term projects of their own. In particular, several interviewees were participants in an Integrative Graduate Education and Research Traineeship (IGERT) program based at the university anchoring their LTER site. These students reported finding support for socialecological research at their sites. When asked if socialecological research existed at his site, one interviewee felt strongly influenced by the work of his site's PI. He told us that the PI had been working over the past decade "towards the integration of the social sciences. I mean, that's what the whole IGERT program has been developed to do." Another student described how, as an IGERT student, she was "automatically involved in the [LTER site] grad community and required to go to the meetings." Students also described different ways that the IGERT program allowed, even required, them to receive training in social-ecological theories, methods, and practice. These included the requirement to pursue a minor in either the social or ecological sciences and to include a collaborative chapter in their dissertations.

\section{LTER Network level}

\section{Conceptualization}

Graduate students had high general recognition of nascent social-ecological research initiatives in the LTER Network, but a more fragmentary awareness of network-level documents and resources available to facilitate this emerging area of investigation. According to the network-wide broad survey, the majority of LTER graduate students were familiar with social-ecological research, recognizing it as an important, interesting, and novel research initiative within the LTER Network. Ninety-two percent of respondents had previously heard about social-ecological research. Graduate students expressed a high level of enthusiasm for the field, with 59\% stating that they were "interested" or "very interested" in social-ecological research and $80 \%$ agreeing or strongly agreeing that social-ecological research is important to the future of the LTER Network.
Even with this enthusiasm, $71 \%$ of the graduate student respondents to the broad survey stated that they had not read the ISSE initiative. One interviewee with a social science background had been working as a research assistant on an LTER social-ecological project for more than six months, yet was not aware of the ISSE or that there were other researchers at the network level engaged in social-ecological research. Conversely, some students were not only knowledgeable about the network but also participated in its higher level organizational and research-oriented activities. Other students had a moderate level of awareness, having been informed of certain network-wide initiatives regarding social-ecological research. However, when asked to describe network-level discussions and strategies, these same students expressed an incomplete understanding of the network itself. For example, one interviewee was quite familiar with the widely circulated press-pulse conceptual diagram, which illustrates how social and ecological research should be integrated and has become the centerpiece of the LTER Network's ISSE initiative. However, the student did not refer to the diagram as an LTER artifact but instead described it as a product of her LTER site.

\section{Practice}

Despite overall awareness of and interest in social-ecological research, relatively few LTER graduate students actually practiced social-ecological research. Findings from the broad survey revealed that the majority, $68 \%$, of LTER graduate students were engaged in strictly ecological research in comparison with social scientific and social-ecological research (Fig. 3). The broad survey results showed that out of the 59 respondents who indicated that they were currently involved in at least one LTER research project, only 12 students, $20 \%$, were involved in social-ecological or social scientific research projects. Moreover, those students actively involved in social-ecological research were still spending a significant amount of time on other ecological research projects. Nine out of the 12 students referenced previously were involved in at least one other ecological science research project. When asked to estimate the amount of total research time spent on their ecological, social, and social-ecological projects, these 12 students reported spending an average of $15 \%$ of their time on social-ecological and social scientific research.

We found a spectrum of network participation and awareness across our interviewees. A student with limited exposure to the network expressed regret for not being aware of the LTER Network earlier in his studies and provided a suggestion for those bringing new students into the network: "If initially I was told I was going to be working [in a network], that would be a great opportunity and resource, but I think it has to be straightaway. Because once you get involved in your research and you have this timeline right in front of you, you're budgeting your time, and it's hard to get involved in other things." 
Fig. 3. Long Term Ecological Research (LTER) graduate student responses to Question 11 from the broad survey: "How many of the following types of research projects are you involved with?"

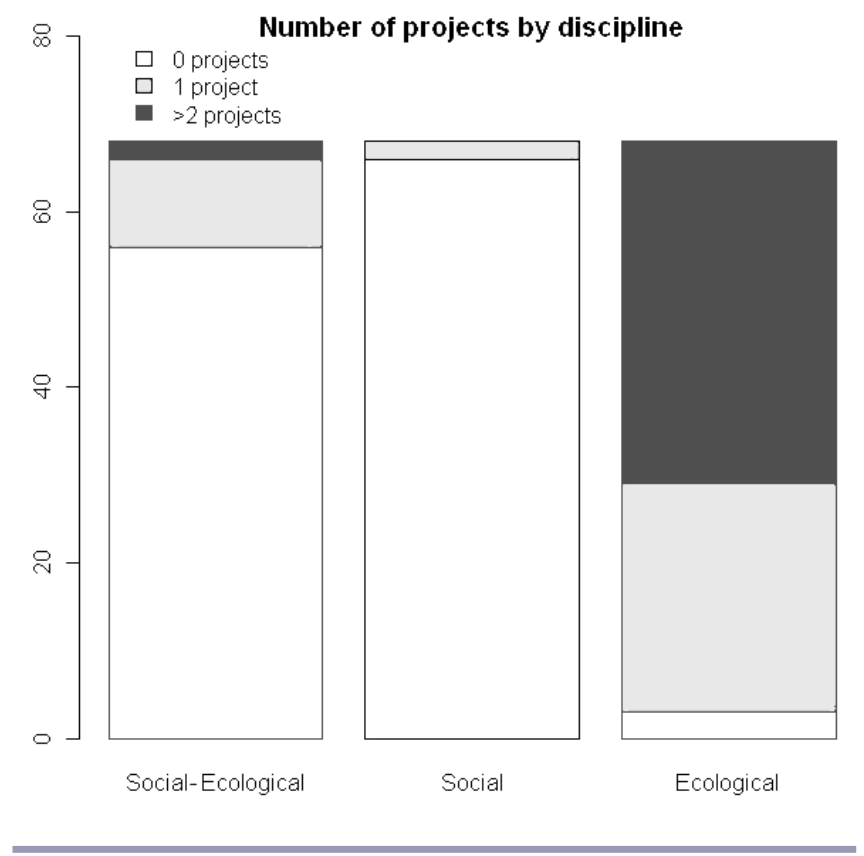

Another student, although in the LTER directory, did not consider himself to be part of the network. He felt this way despite his membership in a cohort of students funded by a grant led by collaborative LTER researchers. As he described his experience: "We didn't really have a great relationship with [the LTER Network] outside of our professor. It was always sort of from outside ... I didn't have the opportunity to get involved." In contrast, other students found the LTER Network to be instrumental in their work and characterized their advisers and/or lead researchers as very vocal about the network and its social-ecological research initiative. As one student described, her project would not exist without the network: "We're doing a cross-site research project with a couple other LTER sites, so using the network to facilitate the cross-site study and collaboration has been really helpful."

\section{CONCLUSION AND RECOMMENDATIONS}

Our research has captured the conceptual challenges confronting graduate students in the LTER Network as the network strives to adopt a novel research program focused on social-ecological scholarship. These conceptual challenges highlight key findings that emerged from our research: (1) At the individual scale, graduate students hold different underlying ideas when they define social-ecological research and experience different modes of social-ecological research in practice in the LTER Network. (2) At the site scale, graduate students involved in social-ecological research often faced institutional, communicative, spatial, and cultural obstacles to their integration into the LTER community. (3) At the network scale, although graduate students were very interested in and aware of social-ecological research in general, they were less aware of specific network-level social-ecological initiatives, and only a small number of graduate students were actually engaged in social-ecological projects. We believe that these challenges are neither unique to the LTER Network nor signs of the ISSE initiative's failure but instead provide fertile ground for learning about the dissemination and adoption of new ideas in network-level science consortiums. At each scale described in our results, we found commonalities in the ways that graduate students successfully overcame such challenges. We discuss these successful strategies and offer suggestions for LTER and other network-level science leaders and personnel to consider as they take on and implement new research initiatives.

\section{Recommendation 1: facilitate the creation, dissemination, and discussion of boundary objects}

Our research demonstrates that LTER graduate students struggle with the term social-ecological and therefore hold a plurality of definitions of this type of research instead of a shared concept of what this term means. In general, shared concepts are critical because they allow interdisciplinary researchers to communicate across disciplines (Pickett 1999, Wear 1999, Heemskerk et al. 2003) and can form a foundation for implementing successful new research initiatives. However, novel concepts like social-ecological research require a certain amount of discussion, practice, and debate to refine (Miller et al. 2008).

One way to focus discussions and engagements with novel research initiatives is for networks to develop boundary objects (Star and Griesemer 1989) to facilitate discussions about novel research concepts and to create a wider collective awareness about them. A boundary object is a concept portrayed through various media, such as a diagram, map, or scientific specimen, that can travel across different scientific communities without losing its meaning, although the interpretations of such meanings may vary across different institutional, geographic, or disciplinary communities.

In the LTER Network, the ISSE diagram (Collins et al. 2011) has acted as a key boundary object. This conceptual map of how social scientific research can be integrated with traditional ecological research has been disseminated, reworked, and used to encourage discussion about the theory and practice of social-ecological research among diverse researchers at LTER sites. Our results showed that some graduate students were actively engaging with the ISSE research framework, but the large majority remained unaware of the ISSE diagram or the ISSE report. Clearly, graduate students had insights to offer about the design of social-ecological research in the LTER 
Network even if they were not aware of the ISSE. Thus, it is important for networks to actively encourage graduate students' awareness of boundary objects and to encourage evaluation and reconceptualization from the ground up as well as from the top down.

\section{Recommendation 2: provide network-level support for communities of practice}

It is important to support communities of practice within largescale research networks. In our research, we found that some students felt as if they were peripheral, rather than integrated, members of their LTER site. In some cases, this was attributable to physical distance from the site. In addition to Grimm and Redman's (2004) discussion as it relates to LTER interdisciplinary research, the "distance matters" issue in collaborative research has been covered extensively elsewhere (Olson and Olson 2000). However, we interviewed several graduate students conducting social-ecological research without a geographic distance barrier who reported a feeling of cultural distance. Miller et al. (2008) addressed the causes behind this cultural distance, suggesting that LTER sites tend to have one dominant research paradigm that is not open to other ideas. The LTER Network has worked to encourage synthetic science across disciplines with the creation of the National Center for Ecological Analysis and Synthesis (Hackett et al. 2008) and to fully integrate social science into the network (Redman et al. 2004). We suggest that these shifts do not always trickle down to the most junior levels of the network. In our results, established communities of practice, such as working groups and integrated training programs, often seemed to help counteract students' sense of distance.

Several students participating in an IGERT program reported finding a supportive community for social-ecological research. Because participants meet frequently, the IGERT structure creates cohesion and opportunities for transmission of interdisciplinary knowledge and insights from higher level personnel to junior personnel. Although we recognize that all IGERT programs are not the same, our interview results bolster the findings of studies that have provided more formal evaluations (Morse et al. 2007, August et al. 2010), offering support for continuation of these programs and perhaps for implementation of similar interdisciplinary training programs at LTER sites that are currently without them. Additionally, the emerging cohort of LTER scientists that work on urban ecology (see Grimm et al. 2000, Pickett et al. 2008) provides a research community in which several students reported finding support. We expect that this and similar self-organized communities of practice will continue to develop as socialecological research becomes the norm in LTER, and we would recommend that research networks support these groups when possible. These types of interdisciplinary communities act as a space for graduate students to collectively respond to and reformulate higher level blueprints like ISSE.
Recommendation 3: ensure that lead researchers and advisers educate current and potential members about the network, across all scales and locales

As our research demonstrates, graduate students involved in social-ecological research often faced institutional, communicative, spatial, and cultural obstacles to their integration into the LTER Network and its research sites. There were students working on social-ecological research without knowledge of the network-level support that exists for this type of integrated research. Few students had read the ISSE initiative, and most were not aware of the explicit support for social-ecological science that is written into the plan. In addition, several students did not become aware of the LTER Network or its resources until well into their degree programs or research projects. At that point, becoming part of the network becomes more of a burden than a benefit.

To overcome this challenge in all research networks, it is important to inform graduate students about the research network and its initiatives as soon as they enter an academic program or become employed by a research study. This must include educating and training potential research advisers because they are largely responsible for overseeing the development and execution of social-ecological research carried out by new network members. Indeed, nearly all of our interviewees indicated that the influence of their graduate advisers or PIs strongly impacted whether or not they felt supported in the pursuit of social-ecological research projects and whether or not they became involved in LTER Network activities.

We offer these suggestions as potential ways to bridge the gap between the senior network personnel who formulate novel research initiatives and the junior researchers who often implement these initiatives. Large-scale, distributed scientific research networks with multidisciplinary, interdisciplinary, and transdisciplinary approaches have changed the way that science is practiced. It is essential to ensure that the next generation of scientists is equipped to carry forward new research initiatives and to continue to advance network-level science.

Responses to this article can be read online at: http://www.ecologyandsociety.org/issues/responses. php/5606

\section{Acknowledgments:}

We thank the LTER Network Office for funding, our faculty mentors Morgan Grove and Laura Ogden, and participants in our "Benefits and Barriers" graduate student working group at the 2009 LTER ASM. Terry Chapin, Dan Childers, Aaron Ellison, David Foster, and Laura Ogden provided 
comments on earlier drafts of the manuscript. This work is a contribution to the Baltimore Ecosystem Study LTER Program, the Central Arizona-Phoenix LTER Program, the Florida Coastal Everglades LTER Program, and Harvard Forest LTER Program through NSF grant numbers DEB-1027188, DEB-0620443, DBI-0620409, and DEB-0423704. Any opinions, findings, and conclusions or recommendations expressed in this paper are those of the authors and do not necessarily reflect the views of the NSF.

\section{LITERATURE CITED}

August, P. V., J. M. Swift, D. Q. Kellogg, G. Page, P. Nelson, J. Opaluch, J. S. Cobb, C. Foster, and A. J. Gold. 2010. The $\mathrm{T}$ Assessment Tool: a simple metric for assessing multidisciplinary graduate education. Journal of Natural Resources and Life Sciences Education 39(1):15-21.

Berg, B. 2007. Qualitative research methods for the social sciences. Sixth edition. Pearson, New York, New York, USA.

Callahan, J. T. 1984. Long-term ecological research. BioScience 34:363-367. http://dx.doi.org/10.2307/1309727

Carpenter, S. R., B. J. Benson, R. Biggs, J. W. Chipman, J. A. Foley, S. A. Golding, R. B. Hammer, P. C. Hanson, P. T. J. Johnson, A. M. Kamarainen, T. K. Kratz, R. C. Lathrop, K. D. McMahon, B. Provencher, J. A. Rusak, C. T. Solomon, E. H. Stanley, M. G. Turner, M. J. V. Zanden, C.-H. Wu, and H. Yuan. 2007. Understanding regional change: a comparison of two lake districts. BioScience 57:323-335. http://dx.doi. org/10.1641/B570407

Collins, S. L., S. R. Carpenter, S. M. Swinton, D. E. Orenstein, D. L. Childers, T. L. Gragson, N. B. Grimm, J. M. Grove, S. L. Harlan, J. P. Kaye, A. K. Knapp, G. P. Kofinas, J. J. Magnuson, W. H. McDowell, J. M. Melack, L. A. Ogden, G. P. Robertson, M. D. Smith, and A. C. Whitmer. 2011. An integrated conceptual framework for long-term socialecological research. Frontiers in Ecology and the Environment 9(6):351-357. http://dx.doi.org/10.1890/100068

Corbin, J., and A. Strauss. 2008. Basics of qualitative research: techniques and procedures for developing grounded theory. Sage, Thousand Oaks, California, USA.

Díaz, S., F. Quétier, D. M. Cáceres, S. F. Trainor, N. PérezHarguindeguy, M. S. Bret-Harte, B. Finegan, M. Peña-Claros, and L. Poorter. 2011. Linking functional diversity and social actor strategies in a framework for interdisciplinary analysis of nature's benefits to society. Proceedings of the National Academy of Sciences of the United States of America 108 (3):895-902. http://dx.doi.org/10.1073/pnas.1017993108

Edmunds, H. 2000. The focus group research handbook. Sage, Thousand Oaks, California, USA.

Eigenbrode, S. D., M. O'Rourke, J. D. Wulfhorst, D. M. Althoff, C. S. Goldberg, K. Merrill, W. Morse, M. Nielsen-
Pincus, J. Stephens, L. Winowiecki, and N. A. Bosque-Pérez. 2007. Employing philosophical dialogue in collaborative science. BioScience 57(1):55-64. http://dx.doi.org/10.1641/ B570109

Ewel, K. C. 2001. Natural resource management: the need for interdisciplinary collaboration. Ecosystems 4(8):716-722. http://dx.doi.org/10.1007/s10021-001-0040-1

Galison, P. L. 1997. Image and logic: a material culture of microphysics. University of Chicago Press, Chicago, Illinois, USA.

Gilbert, L. E. 1998. Disciplinary breadth and interdisciplinary knowledge production. Knowledge, Technology \& Policy 11 (1-2):4-15. http://dx.doi.org/10.1007/s12130-998-1007-8

Graybill, J. K., S. Dooling, V. Shandas, J. Withey, A. Greve, and G. L. Simon. 2006. A rough guide to interdisciplinarity: graduate student perspectives. BioScience 56(9):757-763. http://dx.doi.org/10.1641/0006-3568(2006)56[757:ARGTIG] 2.0.CO;2

Graybill, J. K., and V. Shandas. 2010. Doctoral student and early academic career perspectives on interdisciplinarity. Pages 404-418 in R. Frodeman, R. T. Klein, and C. Mitcham, editors. The Oxford handbook on interdisciplinarity. Oxford University Press, Cambridge, UK.

Grimm, N. B., J. M. Grove, S. T. A. Pickett, and C. L. Redman. 2000. Integrated approaches to long-term studies of urban ecological systems. BioScience 50:571-584. http://dx.doi. org/10.1641/0006-3568(2000)050[0571:IATLTO]2.0.CO;2

Grimm, N. B., and C. L. Redman. 2004. Approaches to the study of urban ecosystems: the case of Central ArizonaPhoenix. Urban Ecosystems 7:199-213. http://dx.doi. org/10.1023/B:UECO.0000044036.59953.a1

Haberl, H., V. Winiwarter, K. Andersson, R. Ayres, C. Boone, A. Castillo, G. Cunfer, M. Fischer-Kowalski, W. R. Freudenburg, E. Furman, R. Kaufmann, F. Krausmann, E. Langthaler, H. Lotze-Campen, M. Mirtl, C. L. Redman, A. Reenberg, A. Wardell, B. Warr, and H. Zechmeister. 2006. From LTER to LTSER: conceptualizing the socio-economic dimension of long-term socio-ecological research. Ecology and Society 11(2): 13. [online] URL: http://www. ecologyandsociety.org/vol11/iss2/art13/

Hackett, E. J., J. N. Parker, D. Conz, D. Rhoten, and A. Parker. 2008. Ecology transformed: NCEAS and the changing patterns of ecological research. Pages 277-296 in G. Olson, A. Zimmerman, and N. Bos, editors. Scientific collaboration on the Internet. MIT Press, Cambridge, Massachusetts, USA.

Haraway, D. 1988. Situated knowledges: the science question in feminism and the privilege of partial perspective. Feminist Studies 14(3):575-599. http://dx.doi.org/10.2307/3178066 
Haythornthwaite, C., K. J. Lunsford, G. C. Bowker, and B. C. Bruce. 2006. Challenges for research and practice in distributed, interdisciplinary collaboration. Pages 143-166 in C. Hine, editor. New infrastructures for knowledge production: understanding e-science. IGI Global, Hershey, Pennsylvania, USA. http://dx.doi.org/10.4018/978-1-59140-717-1. $\underline{\mathrm{ch} 007}$

Heemskerk, M., K. Wilson, and M. Pavao-Zuckerman. 2003. Conceptual models as tools for communication across disciplines. Conservation Ecology 7(3): 8. [online] URL: http://www.consecol.org/vol7/iss3/art8/

Johnson, J. C., R. R. Christian, J. W. Brunt, C. R. Hickman, and R. B. Waide. 2010. Evolution of collaboration within the US Long Term Ecological Research Network. BioScience 60 (11):931-940. http://dx.doi.org/10.1525/bio.2010.60.11.9

Karasti, H., and K. S. Baker. 2008. Digital data practices and the Long Term Ecological Research program growing global. International Journal of Digital Curation 3(2):42-58. http:// dx.doi.org/10.2218/ijdc.v3i2.57

Lélé, S., and R. B. Norgaard. 2005. Practicing interdisciplinarity. BioScience 55(11):967-975. http://dx.doi. org/10.1641/0006-3568(2005)055[0967:PI]2.0.CO;2

MacMynowski, D. P. 2007. Pausing at the brink of interdisciplinarity: power and knowledge at the meeting of social and biophysical science. Ecology and Society 12(1): 20. [online] URL: http://www.ecologyandsociety.org/vol12/iss1/ $\underline{\operatorname{art} 20 /}$

Miller, T. R., T. D. Baird, C. M. Littlefield, G. Kofinas, F. S. Chapin III, and C. L. Redman. 2008. Epistemological pluralism: reorganizing interdisciplinary research. Ecology and Society 13(2): 46. [online] URL: http://www. ecologyandsociety.org/vol13/iss2/art46/

Morse, W. C., M. Nielsen-Pincus, J. Force, and J. Wulfhorst. 2007. Bridges and barriers to developing and conducting interdisciplinary graduate-student team research. Ecology and Society 12(2): 8. [online] URL: http://www.ecologyandsociety. org/vol12/iss $2 /$ art $8 /$

Nature Editorial Board. 2003. Who'd want to work in a team? Nature 424(6944):1. http://dx.doi.org/10.1038/424001a

Norgaard, R. B., and P. Baer. 2005. Collectively seeing complex systems: the nature of the problem. BioScience 55 (11):953-960. http://dx.doi.org/10.1641/0006-3568(2005)055 [0953:CSCSTN]2.0.CO;2

Olson, G. M., and J. S. Olson. 2000. Distance matters. HumanComputer Interaction 15(2):139-178.

Pickett, S. T. A., W. R. Burch Jr., and J. M. Grove. 1999. Interdisciplinary research: maintaining the constructive impulse in a culture of criticism. Ecosystems 2(4):302-307. http://dx.doi.org/10.1007/s100219900081

Pickett, S. T. A., M. L. Cadenasso, J. M. Grove, P. M. Groffman, L. E. Band, C. G. Boone, W. R. Burch Jr., C. S. B. Grimmond, J. Hom, J. C. Jenkins, N. L. Law, C. H. Nilon, R. V. Pouyat, K. Szlavecz, P. S. Warren, and M. A. Wilson. 2008. Beyond urban legends: an emerging framework of urban ecology, as illustrated by the Baltimore Ecosystem Study. BioScience 58(2):139-150. http://dx.doi.org/10.1641/B580208

Porter, J. H., E. Nagy, T. K. Kratz, P. Hanson, S. L. Collins, and P. Arzberger. 2009. New eyes on the world: advanced sensors for ecology. BioScience 59(5):385-397. http://dx.doi. org/10.1525/bio.2009.59.5.6

Price, M. F., 1990. Humankind in the biosphere: the evolution of international interdisciplinary research. Global Environmental Change 1(1):3-13. http://dx.doi.org/10.1016/0959-3780(90) 90003-R

Redman, C. L., J. M. Grove, and L. H. Kuby. 2004. Integrating social science into the Long-Term Ecological Research (LTER) Network: social dimensions of ecological change and ecological dimensions of social change. Ecosystems 7 (2):161-171. http://dx.doi.org/10.1007/s10021-003-0215-Z

Rhoten, D., and A. Parker. 2004. Risks and rewards of an interdisciplinary research path. Science 306(5704):2046. http://dx.doi.org/10.1126/science.1103628

Ryan, G. W., and H. R. Bernard. 2003. Techniques to identify themes. Field Methods 15(1):85-109. http://dx.doi. org/10.1177/1525822X02239569

Shapin, S., and S. Schaffer. 1985. Leviathan and the air-pump. Princeton University Press, Princeton, New Jersey, USA.

Star, S. L., and J. R. Griesemer. 1989. Institutional ecology, "translations" and boundary objects: amateurs and professionals in Berkeley's Museum of Vertebrate Zoology, 1907-39. Social Studies of Science 19(3):387-420. http://dx. doi.org/10.1177/030631289019003001

U.S. Long Term Ecological Research (LTER) Network. 2007. The decadal plan for LTER integrative science for society and the environment. LTER Network Office Publication Series, No. 24, Albuquerque, New Mexico, USA. [online] URL: http://intranet2.1ternet.edu/node/2447

Wear, D. N. 1999. Challenges to interdisciplinary discourse. Ecosystems 2(4):299-301. http://dx.doi.org/10.1007/s100219900080

Wilson, E. O. 1999. Consilience: the unity of knowledge. Vintage Books, New York, New York, USA. 


\section{APPENDIX 1}

Broad survey about graduate student socio-ecological experiences and attitudes in the LTER Network

\section{SURVEY INTRODUCTION}

This survey is about graduate student attitudes towards and experiences with socio-ecological research in the LTER Network. This survey should take approximately 10-15 minutes of your time. It will contribute to a research study that a group of LTER graduate students has organized as follow-up to a 2009 ASM working group on this topic. Survey results will be used as data for a research publication and will be presented to LTER leadership. Your responses will be kept confidential. Your name or other personal information will not be publicly linked to your survey responses. Thank you for your time! Should you have any questions about this survey or our work, please contact us.

\section{SECTION 1: SOCIO-ECOLOGICAL RESEARCH in the LTER NETWORK}

This first section of this survey asks you about your familiarity with socio-ecological research and your views of it. (Section 1 of 4 )

Q1 Since joining the LTER network, how often do you typically hear about socio-ecological research?

O Never (1)

O Rarely (2)

A few times (3)

Frequently (4)

All the time (5)

Q2 How interested are you in socio-ecological research?

O Very disinterested (1)

D Disinterested (2)

Neither interested or disinterested (3)

Interested (4)

Very interested (5)

Q3 What socio-ecological research topics interest you?

Q4 What other kinds of research topics interest you? 
Q5 Please indicate how much you agree or disagree with the following statements:

\begin{tabular}{|c|c|c|c|c|c|}
\hline & $\begin{array}{c}\text { Strongly } \\
\text { Disagree (1) }\end{array}$ & Disagree (2) & $\begin{array}{c}\text { Neither Agree } \\
\text { nor Disagree } \\
\text { (3) }\end{array}$ & Agree (4) & $\begin{array}{c}\text { Strongly } \\
\text { Agree (5) }\end{array}$ \\
\hline $\begin{array}{l}\text { I can clearly } \\
\text { define what } \\
\text { socio- } \\
\text { ecological } \\
\text { research is. } \\
\text { (2) }\end{array}$ & 0 & $\mathrm{O}$ & O & O & $\mathrm{O}$ \\
\hline $\begin{array}{l}\text { I would like } \\
\text { to learn more } \\
\text { about what } \\
\text { socio- } \\
\text { ecological } \\
\text { research is. } \\
\text { (3) }\end{array}$ & $\mathrm{O}$ & 0 & $\mathrm{O}$ & O & O \\
\hline $\begin{array}{l}\text { I would like } \\
\text { to be (more) } \\
\text { involved as a } \\
\text { researcher in } \\
\text { a socio- } \\
\text { ecological } \\
\text { research } \\
\text { project. (4) }\end{array}$ & O & $\mathrm{O}$ & O & $\mathrm{O}$ & $\mathrm{O}$ \\
\hline $\begin{array}{l}\text { I am able to } \\
\text { spend as } \\
\text { much time } \\
\text { studying } \\
\text { socio- } \\
\text { ecological } \\
\text { research } \\
\text { topics as I } \\
\text { would like. } \\
\text { (7) }\end{array}$ & O & 0 & O & $\mathrm{O}$ & O \\
\hline
\end{tabular}

If the respondent indicates that he or she "disagrees" or "strongly disagrees" with the statement "I am able to spend as much time studying socio-ecological research topics as I would like" in question 5, then ask:

Q5A Why are you not able to spend as much time studying socio-ecological topics as you would like?

Q6 In your own words, how would you define socio-ecological research? 
Q7 Please indicate how much you agree or disagree with the following statements:

\begin{tabular}{|c|c|c|c|c|c|}
\hline & $\begin{array}{c}\text { Strongly } \\
\text { Disagree (1) }\end{array}$ & Disagree (2) & $\begin{array}{l}\text { Neither Agree } \\
\text { nor Disagree } \\
\text { (3) }\end{array}$ & Agree (4) & $\begin{array}{l}\text { Strongly } \\
\text { Agree (5) }\end{array}$ \\
\hline $\begin{array}{l}\text { Within the } \\
\text { LTER } \\
\text { network, } \\
\text { socio- } \\
\text { ecological } \\
\text { research has } \\
\text { an agreed- } \\
\text { upon } \\
\text { definition. (1) }\end{array}$ & 0 & 0 & 0 & 0 & 0 \\
\hline $\begin{array}{l}\text { Socio- } \\
\text { ecological } \\
\text { research is an } \\
\text { emerging } \\
\text { research area } \\
\text { in the LTER } \\
\text { network. (5) }\end{array}$ & 0 & $\mathrm{O}$ & $\mathrm{O}$ & $\mathrm{O}$ & $\mathrm{O}$ \\
\hline $\begin{array}{l}\text { Socio- } \\
\text { ecological } \\
\text { research is } \\
\text { important to } \\
\text { the future of } \\
\text { the LTER } \\
\text { network. (6) }\end{array}$ & 0 & $\mathrm{O}$ & $\mathrm{O}$ & $\mathrm{O}$ & 0 \\
\hline $\begin{array}{l}\text { The LTER } \\
\text { Network } \\
\text { provides } \\
\text { adequate } \\
\text { support for } \\
\text { socio- } \\
\text { ecological } \\
\text { research. (7) }\end{array}$ & $\mathrm{O}$ & $\mathrm{O}$ & 0 & 0 & $\mathrm{O}$ \\
\hline
\end{tabular}




\section{SECTION 2. YOUR RESEARCH}

We are next going to ask you some questions about the research projects you are involved with. (Section 2 of 4)

Q8 My research takes place at (check the option that best describes your situation):

O One LTER site (1)

O Multiple LTER sites (2)

O LTER site(s) and ULTRA site(s) (3)

O LTER site(s) and NEON site(s) (4)

O LTER site(s) and National Park Service site(s) (5)

O LTER site(s) and field sites or stations affiliated with another organization (e.g. US Forest Service, a University. Please specify) (6)

LTER site(s) and other sites (please specify) (7)

Q9 Is your research collaborative? Collaborative research typically involves actively working with other colleagues as part of a larger research team to answer a research question. Researchers work within their own disciplines to make a contribution to group data collection and analysis.

O Yes (1)

O No (2)

O Not sure (3)

Q10 Is your research interdisciplinary? Interdisciplinary research synthesizes the theories and methods of multiple academic disciplines (e.g. anthropology and biology) to answer a research question.

O Yes (1)

No (2)

O Not sure (3)

Q11 How many of the following types of research projects are you involved with? Socio-Ecological (1) Social Science (2) Ecological science (3) Other (4)

If the respondent indicates that they are involved in one or more socio-ecological research projects in their response to Q11, then ask him/her these questions:

Q11A What statement best describes the socio-ecological project(s) you are currently working on?

This project is for my Master's thesis. (1)

This project is for my dissertation research. (2)

O This is an LTER-related side project (3)

This is a non-LTER side project. (5)

Other (please specify:) (4)

Q11B What agencies or entities provide the funding for the socio-ecological research you are involved in? 
Environmental Protection Agency (EPA) (1)

National Science Foundation (NSF) (2)

National Oceanic and Atmospheric Administration (NOAA) (3)

प My university (4)

Private foundation (please specify) (5)

$\square$ Other (please specify) (6)

Q11C Because you are working on a socio-ecological research project, we would like to ask you some addition questions about your experiences at a later date. Would you be willing to participate in a follow-up interview?
O Yes (1)
No (2)

If the respondent selects "yes" to Question 11B, then ask them:

Q11C-1 Please include your contact information (name, email and phone number) so that we may get in touch with you:

Q12 About what percentage of your research time is spent on (total should add up to 100\%): Socio-ecological research projects (1) Social science research projects (2) Ecological research projects (3)

Other research projects (please specify):

Q13 Ideally, how would you like to spend your research time? (Total should add up to $100 \%$ ) Socio-ecological research projects (1) Social science research projects (2) Ecological research projects (3) Other research projects (please specify):

Q14 Please indicate how much you agree or disagree with the following statements:

\begin{tabular}{|c|c|c|c|c|c|}
\hline & $\begin{array}{c}\text { Strongly } \\
\text { Disagree (1) }\end{array}$ & Disagree (2) & $\begin{array}{c}\text { Neither } \\
\text { Agree nor } \\
\text { Disagree (3) }\end{array}$ & Agree (4) & $\begin{array}{c}\text { Strongly } \\
\text { Agree (5) }\end{array}$ \\
\hline $\begin{array}{l}\text { Graduate } \\
\text { students } \\
\text { benefit from } \\
\text { conducting } \\
\text { socio- } \\
\text { ecological } \\
\text { research. (1) }\end{array}$ & $\mathrm{O}$ & $\mathrm{O}$ & $\mathrm{O}$ & 0 & $\mathrm{O}$ \\
\hline $\begin{array}{l}\text { Graduate } \\
\text { students face } \\
\text { challenges } \\
\text { when } \\
\text { conducting }\end{array}$ & $\mathrm{O}$ & O & $\mathrm{O}$ & $\mathrm{O}$ & $\mathrm{O}$ \\
\hline
\end{tabular}




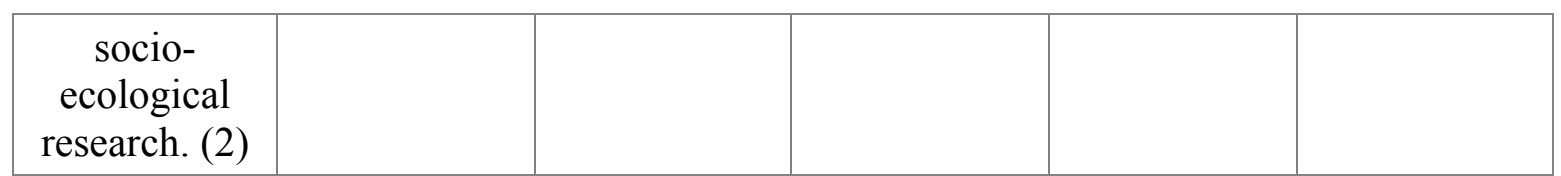

If the respondent indicates that he or she "agrees" or "strongly agrees" with the statement "Graduate students face challenges when conducing socio-ecological research" in question 14, then ask:

Q14A Select the challenges related to socio-ecological research that you think are the most difficult.
$\square$ Funding (1)
Institutional support (2)
Advisor support (3)
Peer support (4)
$\square$ Theoretical issues (5)
Methodological issues (6)
Finding collaborators (7)
Bridging disciplines (8)
Time (10)
Other (please specify) (9)

\section{SECTION 3: OPPORTUNITIES}

This next set of questions asks about the kinds of opportunities available at your institution, your LTER site and through the LTER network to learn more about socio-ecological topics. (Section 3 of 4 )

Q15 Have you ever taken a class on socio-ecological research (either theory or methods)?

O Yes (1)

O No (2)

Not sure (3)

If respondent answers "no" or "not sure" to question 15 , then ask:

Q15A How interested would you be in taking a course on socio-ecological research?

V Very disinterested (1)

O Disinterested (2)

O Neither interested or disinterested (3)

O Interested (4)

Very interested (5)

If respondent answers "yes" to question 15 , then ask:

Q15B Did your home academic institution host this course on socio-ecological research?

O Yes (1)

No (2)

Not sure (3)

Q15C Did you take the "From Yardstick to Gyroscope" class offered through the LTER 
Network?
Y Yes (1)
No (2)
Not sure (3)
I am not familiar with this course. (4)

Q16 Please indicate how much you agree or disagree with the following statements:

\begin{tabular}{|c|c|c|c|c|c|}
\hline & $\begin{array}{c}\text { Strongly } \\
\text { Disagree (1) }\end{array}$ & Disagree (2) & $\begin{array}{c}\text { Neither Agree } \\
\text { nor Disagree } \\
\text { (3) }\end{array}$ & Agree (4) & $\begin{array}{l}\text { Strongly } \\
\text { Agree (5) }\end{array}$ \\
\hline $\begin{array}{l}\text { The LTER } \\
\text { network } \\
\text { should } \\
\text { periodically } \\
\text { offer a } \\
\text { graduate } \\
\text { course on } \\
\text { socio- } \\
\text { ecological } \\
\text { research } \\
\text { methods. (1) }\end{array}$ & 0 & 0 & $\mathrm{O}$ & $\mathrm{O}$ & $\mathrm{O}$ \\
\hline $\begin{array}{l}\text { The LTER } \\
\text { network } \\
\text { should } \\
\text { periodically } \\
\text { offer a } \\
\text { graduate } \\
\text { course on } \\
\text { socio- } \\
\text { ecological } \\
\text { theory. }(2)\end{array}$ & 0 & 0 & 0 & 0 & 0 \\
\hline $\begin{array}{l}\text { I would be } \\
\text { interested in a } \\
\text { summer } \\
\text { workshop } \\
\text { that would } \\
\text { expose me to } \\
\text { socio- } \\
\text { ecological } \\
\text { research at } \\
\text { other LTER } \\
\text { sites. (3) }\end{array}$ & $\mathrm{O}$ & $\mathrm{O}$ & $\mathrm{O}$ & O & O \\
\hline $\begin{array}{c}\text { I would be } \\
\text { interested in a } \\
\text { short }\end{array}$ & 0 & O & $\mathrm{O}$ & 0 & $\mathrm{O}$ \\
\hline
\end{tabular}




\begin{tabular}{|c|l|l|l|l|}
\hline fellowship-in- & & & \\
residence at \\
another \\
LTER site, so \\
I could learn \\
how to carry \\
out a specific \\
socio- \\
ecological \\
method or to \\
collect & & & & \\
specific data. & & & \\
(4) & & & \\
\hline
\end{tabular}

Q17 Do you participate in a reading group on socio-ecological research?

$\mathrm{O}$ Yes (1)

O No (3)

Not sure (2)

If respondent answers "yes" to question 17, then ask:

Q17A Is this reading group offered through your LTER site?

O Yes (1)

O No (2)

Unsure (3)

If respondent answers "no" or "not sure" to question 17 or "no" to question 17A, then ask:

Q17B Do you think your LTER site should offer a reading group on socio-ecological research?
Yes (1)
O No (2)
Not sure (3)

Q18 Does your LTER site bring in speakers to discuss socio-ecological research topics?

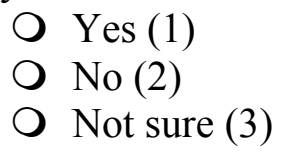

If respondent answers "yes" to question 18, then ask:

Q18A Approximately how often does your site bring in these speakers?

Once a Week (1)

Once a Month (2)

O Every 4 Months (3)

Every 6 Months (4)

Once a Year (5)

If respondent answers "no" or "not sure" to question 18, then ask: 
Q18B Do you think your LTER site should offer a speaker series on socio-ecological research?
O Yes (1)
O No (2)
O Not sure (3)

Q19 Does your academic institution bring in speakers to discuss socio-ecological topics?

O Yes (1)

O No (3)

Not sure (2)

Q20 Do you know of any socio-ecological research projects currently being conducted at your LTER site?

O Yes (1)

O No (2)

Not sure (3)

\section{SECTION 4: DEMOGRAPHIC QUESTIONS}

In this last set of questions, we are going to ask you some questions about yourself. (Section 4 of 4)

Q21 I am currently a:

O Masters student (professional program) (1)

O Masters student (thesis-based program) (2)

O PhD student (3)

O Post-doctoral researcher (4)

Other (please specify): (5)

If respondent answers "Masters student (professional program)" or "Masters student (thesisbased)" to question 21, then ask:

Q21A What year are you in your Master's program?

O First year (1)

Second year (2)

O Third year (3)

O Fourth year (4)

O Other (5)

If respondent answers "PhD Student" to question 21, then ask:

$\mathrm{Q} 21 \mathrm{~B}$ What year are you in your PhD program?

O First year (1)

O Second year (2)

O Third year (3)

O Fourth year (4)

Fifth year (5)

Sixth year (6) 


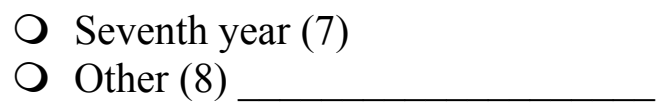

If respondent answers "Post-doctoral researcher" to question 21, then ask:

$\mathrm{Q} 21 \mathrm{C}$ How many years ago did you get your PhD?

O One year (1)

Two years (2)

Three years (3)

Four years (4)

Five years (5)

More than five years (6)

Q22 What is your age?

Under 18 (1)

O $18-22(2)$

O 23-27 (3)

O $28-32$ (4)

O $33-37(5)$

O $38-42$ (6)

O $43-47$ (7)

O $48-54(8)$

O Over 55 (9)

Q23 What is your gender?

Q24 Are you currently affiliated with the Long Term Ecological Research Network (LTER)?

$\bigcirc$ Yes (1)

No (2)

Not sure (3)

Q25 Are you listed in the LTER directory? (Search at http://search.lternet.edu/dir.php)

O Yes (1)

No (2)

If respondent answers "Yes" to question 25, then ask:

Q25A How long have you been a member of the LTER Network?
O 1 year (1)
2 years $(2)$
O 3 years $(3)$
O 4 years $(4)$
O 5 years $(5)$
O 6 years $(6)$
More than 6 years $(7)$

If respondent answers "No" to question 25, then ask:

Q25B Even though you are not an official member of the LTER Network, do you 
consider your research related to LTER research questions?

O Yes (1)

No (2)

Q26 What LTER site(s) are you affiliated with?

Q27 Is your University within 50 miles of your LTER research site(s)?

$\square$ Yes (1)

No (2)

Not sure (3)

Q28 Have you read the The Decadal Plan for LTER: Integrative Science for Society and the Environment, published in 2007 ?

O Yes (1)

O No (3)

O Not sure (2)

Q29 What academic discipline(s) do you most closely identify with?

Q30 What academic conferences, workshops, and professional meetings have you attended, if any?

Q31 Do you have anything else you would like to say about socio-ecological research in the LTER network?

SURVEY CLOSING: You are now finished with the survey! Thank you for your time. Your answers are very valuable. 


\section{APPENDIX 2}

Targeted survey about graduate student socio-ecological experiences and attitudes in the LTER Network

\section{SURVEY INTRODUCTION}

Welcome to our survey about graduate student experiences with socio-ecological research in the LTER network. It will only take a few minutes of your time to complete. Your answers are very important and will contribute to a research study that a group of LTER graduate students has organized as follow-up to a 2009 ASM working group on this topic. Please note that your responses will be kept confidential. Your name or other personal information will not be publicly linked to your survey responses. Should you have any questions about this survey or our work, please contact us.

\section{SECTION 1: YOUR SOCIO-ECOLOGICAL RESEARCH PROJECT(S)}

In this first section of the survey, we are going to ask you a few questions about the socioecological research project(s) you are involved with in the LTER network.(Section 1 of 4)

Q1 Are you conducting, have you ever conducted, or are you planning to conduct socioecological research?

- I am currently conducting socio-ecological research (1)

- I am planning to conduct socio-ecological research (2)

- I have previously conducted socio-ecological research (3)

- I am not involved in socio-ecological research (4)

Q2 What is your socio-ecological research project for?

- My Master's thesis (1)

- My PhD dissertation (2)

- My own side project (3)

- My advisor's project (4)

- Other (5):

Q3 Please briefly describe your primary socio-ecological research project (a couple sentences, or copy an abstract).

\section{SECTION 2: PROJECT BACKGROUND}

We are now going to ask you to provide a few more details about your socio-ecological research project. (Section 2 of 4 )

Q4 My research takes place at:

- One LTER site (1)

- Multiple LTER sites (2)

- LTER site(s) and ULTRA site(s) (3)

- LTER site(s) and NEON site(s) (4)

- LTER site(s) and National Park Service site(s) (5)

- LTER site(s) and field sites or stations affiliated with another organization (e.g. US Forest Service, a University, please specify) (6) 
- LTER site(s) and other sites (please specify) (7)

Q5 Is your research collaborative? Collaborative research is where you are actively working with other colleagues as part of a larger research team to answer a research question.

○ Yes (1)

- No (2)

- Not sure (3)

Q6 Is your research interdisciplinary? Interdisciplinary research synthesizes the theories and methods of multiple academic disciplines (e.g. anthropology and biology) to answer a research question.

○ Yes (1)

- No (3)

- Not sure (2)

Q7 What academic discipline(s) do you most closely identify with?

SECTION 3: DEFINING SOCIO-ECOLOGICAL RESEARCH AND ITS CHALLENGES In this next section, we will ask you some general questions about socio-ecological research. (Section 3 of 4)

Q8 In your own words, how would you define socio-ecological research?

Q9 Do you think there is an agreed-upon definition of socio-ecological research among LTER researchers?

○ Yes (1)

- No (2)

- Not sure (3)

Q10 How would you rate the following challenges associated with socio-ecological research?

\begin{tabular}{|c|c|c|c|}
\hline Funding (1) & Not problematic (1) & $\begin{array}{c}\text { Somewhat } \\
\text { problematic (2) }\end{array}$ & $\begin{array}{c}\text { Highly problematic } \\
\text { (3) }\end{array}$ \\
\hline $\begin{array}{c}\text { Institutional support } \\
\text { (2) }\end{array}$ & & \\
Advisor support (3) & & & \\
Peer support (4) & & \\
Theoretical issues (5) & & \\
Methodological issues & & \\
(6) & & \\
Finding collaborators & & & \\
(7) & & \\
Bridging disciplines & & \\
\hline
\end{tabular}




\begin{tabular}{|c|l|l|l|}
\hline$(8)$ & & \\
Time (9) & & & \\
\hline
\end{tabular}

\section{SECTION 4: DEMOGRAPHICS}

In the next set of questions, we are going to ask you some questions about yourself. (Section 4 of 4)

Q11 I am currently a:

- Masters student (professional program) (1)

- Masters student (thesis-based program) (2)

- PhD student (3)

- Post-doctoral researcher (4)

- Other (please specify): (5)

If respondent answers "Masters student (professional program)" or "Masters student (thesisbased)" to question 11, then ask:

Q11A What year are you in your Master's program?

- First year (1)

- Second year (2)

- Third year (3)

- Fourth year (4)

- Other (5)

If respondent answers "PhD Student" to question 11, then ask:

Q11B What year are you in your Ph.D program?

- First year (1)

- Second year (2)

- Third year (3)

- Fourth year (4)

- Fifth year (5)

- Sixth year (6)

- Seventh year (7)

- Other (8)

If respondent answers "Post-doctoral researcher" to question 11, then ask:

Q11C: How many years ago did you receive your $\mathrm{PhD}$ ?

- One year (1)

- Two years (2)

- Three years (3)

- Four years (4)

- Five years (5)

- More than five years (6)

Q12 What is your age? 
- Under $18(1)$

- $18-22(2)$

○ $23-27(3)$

○ $28-32(4)$

○ $33-37(5)$

- $38-42(6)$

○ $43-47(7)$

- $48-54(8)$

- Over $55(9)$

Q13 What is your gender?

Q14 Are you affiliated with the Long Term Ecological Research Network (LTER)?

○ Yes (1)

- No (2)

- Not sure (3)

Q15 Are you listed in the LTER directory? (Search at http://search.lternet.edu/dir.php)

- Yes (1)

- No (2)

If respondent answers "Yes" to question 15, then ask:

Q15A How long have you been a member of the LTER Network?
○ 1 year (1)
- 2 years $(2)$
- 3 years $(3)$
○ 4 years $(4)$
- 5 years $(5)$
- 6 years $(6)$
- More than 6 years (7)

Q16 What LTER site(s) are you affiliated with?

Q17 Would you be willing to participate in a follow-up interview about your experiences with socio-ecological research within the LTER network?

○ Yes (1)

- No (2)

If respondent answers "No" to Q17, then skip to End of Survey If respondent answers "Yes" to Q17, then ask:

Q17A Thanks for saying "yes"! Please provide your contact information below (name, e-mail address and phone number) so that we may get in touch with you. Please note that your contact information will be kept confidential at all times:

SURVEY CLOSING: You are now finished with the survey! Thank you for your time. Your answers are very valuable. 


\section{APPENDIX 3}

Interview guide

\section{Theme 1: Individual Socio-Ecological Projects and Research Sites}

Please tell me about the socio-ecological project or projects you are currently working on.

Prompts

- How did you become a part of this project?

- Why did you choose this topic? Were there any other topics that you were also considering?

- How does this research project relate to your graduate studies? Is this your main research project?

In doing this research, who do you typically interact with? Where are they located?

You're at the [LTER site], right? Can you tell me about the kind of research people do there?

Prompts

- How much socio-eco work goes on?

- Does you site actively support socio-eco research? In what ways?

What about at your department/program - are they supportive of socio-eco research?

Prompt

- Are many of your peers are doing socio-eco research?

\section{Theme 2: Socio-Ecological Research In General}

(Why) do you think socio-ecological research is important?

What kind of work do you think is cutting edge in socio-ecological research?

Do you keep up with other people doing socio-ecological research? Who are they and what are they doing?

Are there any conferences that you like to go to? Is there anyone you would really like to meet?

How do you describe socio-ecological research?

\section{Prompts}

- Try to get them to talk about socio-ecological vs. purely ecological or purely social science research, if they get onto the topic [but don't lead them]. 


\section{Theme 3: Challenges and Barriers}

Ask them about the challenges they have run into while conducting socio-ecological research. [Pick a few challenges that were ranked high in their survey and reword the questions below to capture these themes, as necessary]

\section{Prompts}

- Tell me about your methods. What kinds of methods do/did you use for your project? How did you come up with them? Can you remember any particular problems that came up when you were defining/applying these?

- Tell me about the theories that guide your project. How did you decide to engage with them? Can you remember any particular issues that came up?

- Tell me about what it is like working across multiple disciplines.

- Tell me about time management. Walk me through an average week. What would make it easier for you to do socio-eco research?

What other challenges or problems have you experienced in doing your research?

Do you think any of these problems are specific to graduate students?

Prompts

- Do you think some graduate students have a harder time than others?

If you could do your research/dissertation/proposal over again, would you do anything differently?

\section{Theme 4: Resources and Solutions}

Tell me about your funding. Who funds your project?

Prompts

- How easy or difficult is it to get funding for socio-ecological research?

Who has been the most helpful in getting your research off the ground?

Prompts

- How helpful has the LTER network been for your research?

- What kinds of resources does the LTER network provide? [If they don't mention it, then ask]: Do you interact with people from other LTER sites about your work?

- Do you tap into other social science or ecological research networks outside the LTER?

What do you think the LTER network can do to help with some of the problems you mentioned?

What advice would you give to a graduate student who is just starting out and who is interested in doing socio-eco research?

\section{Theme 5: The LTER Network}

How would you describe the LTER to somebody who knew nothing about it? 
When did you become part of the LTER? Who got you involved? [Keep this broad; let them answer for either the network or their site]

If he/she isn't a member of the LTER network, then ask him/her: Tell me more about why you aren't a member of the LTER network?

Prompts

- Even though you aren't a member, do you think your research is important the LTER network? Why?

How important is the LTER network for your research? 